\title{
An Overview of Education and Training of Medical Informatics in India
}

\author{
S. N. Sarbadhikari', S. B. Gogiaª \\ ${ }^{1}$ Founding Director, CAL2CAL Institute, Coimbatore 641 028, and \\ Editor-in-Chief, Indian Journal of Medical Informatics \\ ${ }^{2}$ Society for Administration of Telemedicine and Healthcare Informatics (SATHI), 28/31 Old Rajinder \\ Nagar, New Delhi
}

\section{Introduction}

India is widely recognized as a leader in information and communication technology. It is believed that in health care, Information and communication technology (ICT) in India, while under-utilized, has the potential to make significant contributions. Medical informatics (MI) can be applied to utilize ICT and help impart quality medical education [1-3].

Students' ability to master subject matter is generally limited in faceto-face (F2F) classes. Additionally, students learn at different paces that cannot be easily considered in the conventional didactic or practical classes. Online courses or e-learning provides another learning option $[1,6,7]$

India has been recognized as one of the leaders in Information Technology (IT) amongst the emerging economies. Medical Informatics has however not kept apace. With increasing corporatization of healthcare on the one hand and demand for telemedicine facilities from the government side on the other, a need for trained personnel has only recently become recognized. A need to correct this mismatch between needs and availability is being felt.

The purpose of this paper is to provide an assessment of the existing state of education in medical informatics in India.

\section{Study of Current Status of Medical Informatics Education and Training in India}

\section{Methods}

A postal survey was administered to all known institutions as well as circulated amongst the known eMail groups working in informatics, particularly IAMI (iami_gen@googlegroups.com)

\section{Results}

Details of the courses are presented in Table I.

The School of Telemedicine and Biomedical Informatics in Lucknow is one of the largest and most equipped stand-alone telemedicine facilities which has developed in India over the past years with a budget of over 300 million Rupees (Nearly US\$ 6.5 Million) having been spent on equipment alone.

The Master's level course at Amrita Institute of Medical Sciences has enrolled about 5 students per class since it started in 2005. It is divided into 4 semesters where the first three semesters have structured lectures and practicums. The fourth semester is intended for course work that may be undertaken outside with prior permission.

In general for these courses, most of the students are graduates in medicine 
(allopathic, homeopathic, ayurvedic), allied sciences (nursing, physiotherapy) and medical administrators or graduates in engineering or library and information sciences.

Since most of them are also working, a majority of the courses are parttime and serve as on-job value addition. While the courses $\mathrm{c}$ and $\mathrm{d}$ are mostly face-to-face (with online access to some course materials), the courses $\mathrm{a}, \mathrm{b}$ and e are completely online / distance learning based.

However, most of the courses mentioned here do not directly train for jobs. Therefore, as most of the participants are already working somewhere the question of placement due to the course is not measurable directly. Most of the students are already employed and attend this course to gain further insights into health informatics that they want to pursue. Some of them are interested in getting HL7 Certified after this.

For direct, low level, job and career-based training, as well as imparting IT skills to doctors many are running low-level short term courses and workshops [8]. These are especially important for front office workers and nurses who use hospital information systems, telemedicine based clinics as well as do secretarial work in clinics (Table 1).

International Institute of Health Management Research ( IIHMR) is an institution with 4 branches across India. It runs postgraduate courses in Hospital, Healthcare, Pharma and Healthcare IT Management. The course in Healthcare IT has been developed in association with IAMI.

Its New Delhi branch has launched one year elective specialization in Management of Healthcare IT for their 2 year healthcare management course. The first cohort will be following the course in the last two semesters of 2010. Ten students with previous experience in the following fields have enrolled.- 2 from dental sciences, 3 from ayurvedic medical sciences, 2

Table 1 Courses being offered on medical informatics from India

\begin{tabular}{|c|c|c|c|}
\hline Sl. & Institute & Course & URL \\
\hline$a$ & $\begin{array}{l}\text { Department of Biomedical } \\
\text { Informatics, PSG Institute of } \\
\text { Medical Sciences and } \\
\text { Research, Peelamedu, } \\
\text { Coimbatore } 641004\end{array}$ & $\begin{array}{l}\text { 12-week Cerrificate Course - entirely } \\
\text { online, asynchronous / part-time }\end{array}$ & http://psgimsr.in/online-hi/ \\
\hline$b$ & Health Level Seven India & $\begin{array}{l}\text { 14-week Certificate Course - entirely } \\
\text { online, asynchronous / part-iime }\end{array}$ & http://122.166.102.206/moodle/ \\
\hline$c$ & $\begin{array}{l}\text { Amrita Institute of Medical } \\
\text { Sciences, Kochi, } \\
\text { Kerala } 682041\end{array}$ & $\begin{array}{l}\text { Masters program in medical informatics. } \\
\text { Duration - One year full time contact } \\
\text { session followed by one year project at } \\
\text { candidates desired location. Total } 2 \text { years }\end{array}$ & $\begin{array}{l}\text { hitp://aims.amrita.edu/digital- } \\
\text { health.html }\end{array}$ \\
\hline$d$ & $\begin{array}{l}\text { International Institute of Health } \\
\text { Management Research, } \\
\text { (IIHMR) Plot 3, Sector 18A, } \\
\text { Dwarka, } \\
\text { New Delhi - } 110075\end{array}$ & $\begin{array}{l}\text { Various 2-12 day Workshops on topics of } \\
\text { relevance and some lectures as a part of PG } \\
\text { Diploma in Health and Hospital } \\
\text { Management. } \\
2 \text { months elective training for Management } \\
\text { Students from } 2010 \text { course. } \\
1 \text { year specialization in Management of } \\
\text { Healthcare-IT }\end{array}$ & unw.iihmrdehi.org \\
\hline e & $\begin{array}{l}\text { eHCF School of Medical } \\
\text { Informatics, B-5A/B, 2nd } \\
\text { Floor, Street \#-13, Madhu } \\
\text { Vihar, I P Extension, } \\
\text { Delhi-110092 }\end{array}$ & $\begin{array}{l}\text { 3-month Cerrificate Course - Distance } \\
\text { Learning mode based on print material and } \\
\text { email assignments }\end{array}$ & hitp:///www.ehcfsmi.edu.in/ \\
\hline$f$ & $\begin{array}{l}\text { School of Telemedicine and } \\
\text { Biomedical Informatics, } \\
\text { S.G.P.I.I.M.S., Lucknow, UP, } \\
\text { India }\end{array}$ & $\begin{array}{l}6 \text { months and one year Diploma in } \\
\text { Telemedicine and Elearning. It is providing } \\
\text { training to delegations from India and } \\
\text { abroad on incorporating E Based learning in } \\
\text { the curriculum as well as HMIS systems }\end{array}$ & uww.sgpgi.ac.in \\
\hline
\end{tabular}

from physiotherapy, 1 in occupational therapy, 1 is bachelor of pharmacology, and 1 radiology technician.

\section{Discussion}

\section{Current Status of relevant developments in India}

The Government of India has declared 2010-20 as the "Decade of Innovations" [9]. In line with this theme they have appointed Sam Pitroda as the Prime Minister's Advisor on "Informa- tion, Infrastructure and Innovation" with the rank of a Cabinet Secretary [10,11]. Earlier Mr Pitroda, as the Chairman of the National Knowledge Commission had proposed the development of a Health Information Network for India [12].

In another related development, Nandan Nilekani has also been appointed as Chairman of the Unique Identification Authority of India (UIDAI) with a Cabinet Minister rank and the UIDAI has outlined the role of UID for public health [13]. This has paved the way for creating a nationwide Unique Health ID and a possible 
National Health Information System [14] which will create a huge demand for Health Informatics Professionals.

All the above points towards the likelihood that medical informatics will grow considerably in the coming years in India.

However, working against this is the fact that most of the IT programs in India do not give any special stress on Health IT and often it is only student projects that may be encouraged to explore further. Similarly, a significant majority of hospitals are yet to be digitalized. Moreover, the hi-tech hospitals, being in the corporate sector usually do not view public health as a thrust area, unlike governmental institutions. In India, there are very few full-fledged departments, and most of them are extremely short on human resources. Also, many apparently active research topics in the field of health IT in India, like mHealth, are hardly prospering in an academic setting - industry is taking lead in that area.

\section{Conclusions and Future Directions}

India is recognized to be a leader in software skills, and it is rated high also in medical skills being the second only favored country, after Thailand, for medical tourism [13]. However the combination of the two i.e., Medical Informatics, is still not a recognized career choice. Perhaps after 3-5 years the demand for such courses will increase as the market offers more jobs.

Even newspapers discussing career options are finding "informatics" as a promising area [14]. Therefore, we might expect that the future of medical informatics training in India is likely to show an upward trend very soon.

\section{References}

1. Sarbadhikari SN. Applying health care informatics to improve student learning, Really Good Stuff, Medical Education 2008;42: 1117-8.

2. Sarbadhikari SN. The State of Medical Informatics in India: A Roadmap for optimal organization, J Medical Systems, 2005,29:125-41.

3. Sarbadhikari SN. Basic Medical Education must include Medical Informatics, Indian J Physiol Pharamcol 2004,48(4):395-408.

4. Central Bureau for Health Intelligence, (CBHI) India http://cbhidghs.nic.in/writereaddata/mainlinkFile/ Human\%20Resources\%20in\%20Health\%20Sector.pdf

5. World Health Organization in website http:// www.searo.who.int/EN/Section1243/Section2167/ Section2173.htm retrieved January 2010

6. Sarbadhikari SN. How to design an effective elearning course for medical education, Indian Journal of Medical Informatics. 2008;3(1):3: http://ijmi.org/ index.php/ijmi/article/view/y08i1a3/15 [Subsequently converted into a lecture and posted at Supercourse: http://www.pitt.edu/ super1/lecture/ lec35331/001.htm]

7. Sarbadhikari SN. A Step-by-step Primer for using the Internet for Medical Education, South East Asian Journal of Medical Education 2007,1(1):49 - 51.

8. http://www.dataonweb.com/IAMI/workshop/ Workshop.htm retrieved January 2010
9. http://calcuttatube.com/india-declares-2010-20-asthe-decade-of-innovations-47235/

10. http://business.rediff.com/report/2009/oct/07/techpitroda-is-pms-advisor-on-innovation.htm

11. Financial Express http://www.financialexpress.com news/pitroda-is-advisor-to-pm/526343/

12. National Knowledge Commission, Health Information Network, from website http://www. knowledgecommission.gov.in/recommendations hin.asp retrieved January 2010

13. UIDAI, UID and Public Health, http://uidai.gov.in documents/UIDandPublicHealth.pdf

14. Nilekani N. Personal Communication (on January 12, 2010).

15. Medical Tourism figures for 2007. from website Medical Tourism Statistic - http:// www.discovermedicaltourism.com/statistics/ retrieved January 2010

16. Todi M. Informatics, a road less traveled, Education Express, New Indian Express, November 30, 2009, p.1 and 4 .

\section{Acknowledgements}

The authors thank the following for contributing inputs for this paper

Dr Kumar Menon, Amrita Institute of Medical Sciences, Kochi

Dr Indrajit Bhattacharyya, IIHMR, Delhi

Dr R Prajeesh, Bangalore

Dr Rajeev D Joshi, Pune

Dr S K Misra, SGPGI, Lucknow

Dr Arin Basu, previously in Kolkata

Correspondence to:

Dr Shashi Bhushan Gogia

Immediate Past President IAMI

28/31 Old Raiinder Nagar

New Delhi 110060

India

Tel.: (L) +91 112585 2291, (M) +91 9810126883

E-mail gogia7@gmail.com

http://www.iami.org.in 